\title{
自動車用鋼板の発展の推移について $\mathrm{Al}$ キルド鋼からDual Phase鋼まで——
}

1. 緒言

戦後の廃墟の中から立上った日本の自動車工業と鉄鋼 業は 1980 年に奇しくも共に米国の生産量を上回った. 日本に拈ける自動車工業発展の歴史はそのまま鉄鋼業発 展の歴史であるといえよう。1955 年頃約 260 人/1 台し かなかった我が国の自動車普及率は 30 年後の今日約 3 人/1台まで飛躍的に成長した。 また，世界的にも自動 車の生産量は 1960 年の 1640 万台から 1982 年には 3660 万台と倍増している。

こうした自動車工業発展の跡を自動車用鋼板の進歩と いう側面から振返り，筆者と同じく金属を研究する各位 の参考に供する次第である.

\section{2. 社会情勢の変化と自動車用鋼板}

戦後の 1945 年から直近の 1984 年に至る約 40 年間は まさに激動の時代であった。この間に括ける「自動車お よび自動車用鋼板の生産量」「自動車産業と鉄鋼業にお けるトピックス」「自動車用鋼板の開発経過」「薄鋼板の 成形性研究」といら各項目についてそれらの足跡をまと めると表 1 の様になる。自動車および自動車用鋼板の生 産量を見ると 1960 年頃から目ざましい急成長を遂げた 事が分かる。

1973 年に第 1 次石油ショックが起るまで 鉄鋼業が指 向したものは，如何に優れた「軟質」の自動車用鋼板を 安定供給するかといら事であった，表 1 に見られる様に 1955 年代では平炉製鋼法から酸素上吹き転炉製鋼法へ の転換と，世界に先駆けたオープンコイル焼鈍炉 (OCA 炉) や真空脱ガス装置 (DH, RH) の工業化による低炭素, 低窒素鋼板の開発が注目される成果であった，酸素上吹

* 新日本製鉄株式会社中央研究本部第二技術研究所 薄板研究センター所長

The Development of Steel Sheets for Automobiles;from Al Killed Steel to Dual Phase Steel ; Hiroshi Takechi (R \& D Lab.-II, Nippon Steel Corp., Sagamihara) Keywords : steel sheet automobile, high strength steel, formability, coutinuous cast steel, continuous annealed steel 1984 年 9 月 19 日受理
引山*
き転炉製鋼法の普及によって低窒素鋼が日常のものとな った事は我が国の自動車用鋼板の品質を高める上で画期 的な事であった. 1965 年の前半は $\mathrm{A} 1$ コアキルド鋼や $\mathrm{Ti}$ キルド深絞り用鋼板の開発などキルド鋼を駆使した高級 鋼板開発の時代であったが, 1965 年代後半になると更に 目まぐるしい革新の時期を迎える事になる。すなわち連 続鋳造時代の幕明けと共に連続鋳造向りムド相当自動車 用鋼板の開発がスタートし，また，連続焼鈍ラインの稼 働が始まって薄鋼板の製造工程は一変した。

そしてほぼ時を同じくして勃発した第 1 次石油ショッ クによって自動車軽量化時代が始まり従来の軟質鋼板一 辺倒から加工性に優れた高張力鋼板の開発がスタートす る事になる。連続焼鈍ラインは当初軟質鋼板の製造コス ト切下げ，品質向上を目的に開発されたものであった が，高張力鋼板の製造にも極めて適しているため日本は 自動車用高張力鋼板 (以下 High Strength Steel, HSS と 略す)の開発でも世界的に先鞭をつける事が出来た。 こ の事例は技術的ポテンシャルがあれば突発的な環境变化 にも迅速に対応出来る例として興味深い. 1980 年代に 入ると $6 \mathrm{Hi}$ ロール方式やペアクロスロール方式などの新 鋭大容量ホットストリップミルの稼働が始った. これら が新しい製品にどの様に結びついてゆくかは今後の課題 である.この外カー・メーカーとスチール・メーカーの 共同研究体制といら他国にない組織が我が国自動車用鋼 板発展のために, 非常に大きな貢献をした事を指摘して おかねばならない. 当初コニカルカップ研究会といら名 称で始った共同研究会は近年, 薄鋼板成形技術研究会と 改称されたが, カー・メーカーとスチール・メーカーの 両者に跨る問題点を整理し進路を明らかにして来た。 こ らいら共同研究会があるために例えば低降伏点鋼や高張 力鋼など当時の turning pointを世界に先駆けて乗り越 える事が出来たと考えられる.

それでは次章以下で表 1 に示される主な自動車用鋼板 の幾つかについて簡単に説明を加え，その開発の跡をた どる事とする。 


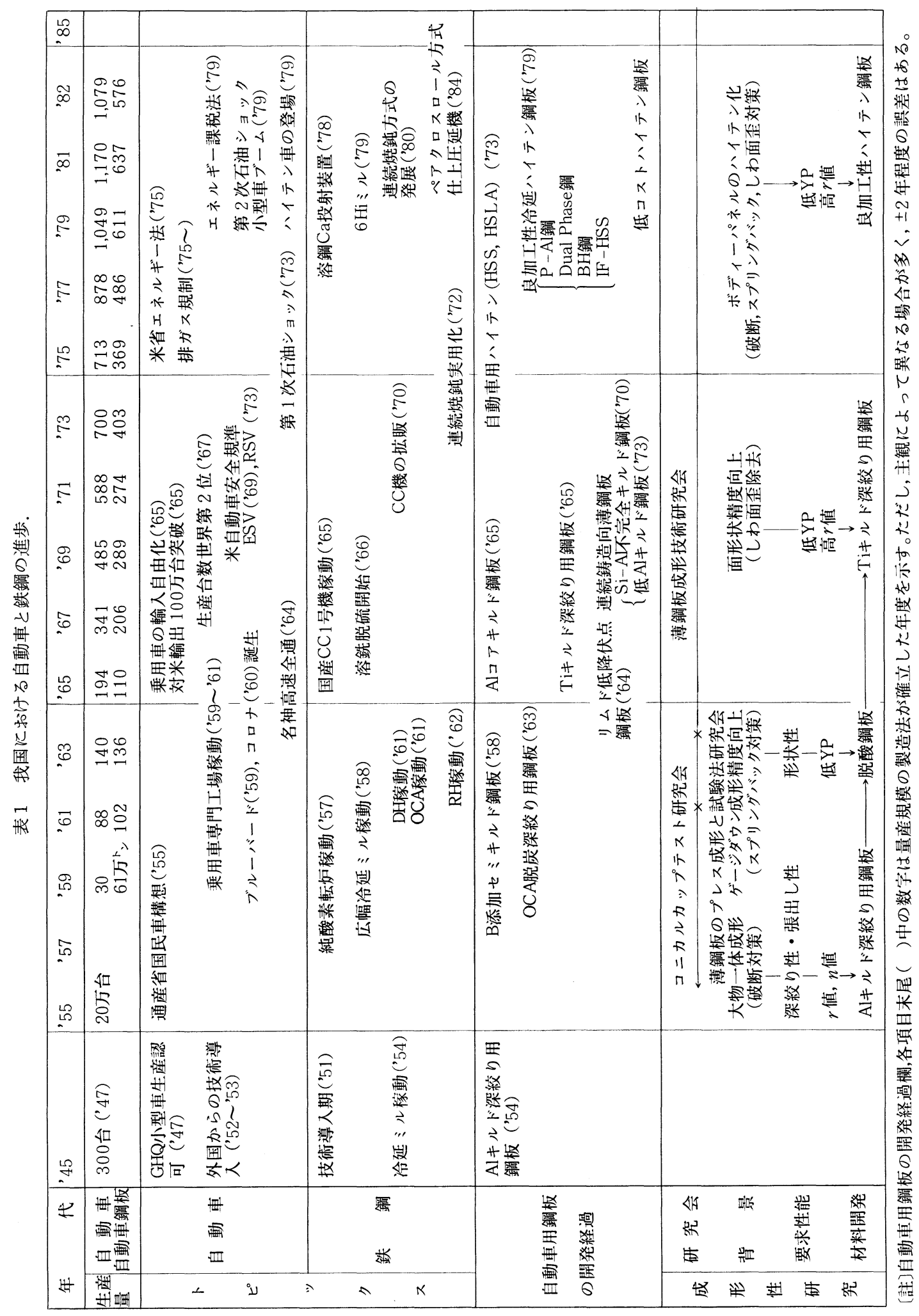




\section{3. 自動車用軟質冷延鋼板の開発}

\section{(1) $\mathrm{AI}$ キルド鋼板}

戦前の我が国では，表面が美麗で加工性に優れた薄鋼 板の製造は困難でその殆どを輸入に頼っていたが，自給 の必要上, 1936 年 5 月, 八幡製鉄所の洞岡地区に高級鋼 板工場といら名称で年産 4 万トンの工場が建設された. 戦後は瓦樂の中からたくましい再建が始まり，1954 年 2 月に富士製鉄の広畑製鉄所に，また，同年 3 月には同じ く八幡製鉄の戸畑地区に 5 スタンドのタンデム冷間圧延 機が稼働を始めている。一方, 我が国に扣ける自動車工 業の勃興期は 1950 1951 年頃で大量生産方式が緒につ いたのは 1960～1961 年頃である.大量生産の開始や車 体デザインの多様化と共に深絞り用鋼板としての $\mathrm{Al}$ キ ルド鋼板に対する需要が年々高まっていった.

1960 年位までは $\mathrm{A} 1$ キルド鋼板の深絞り性はパンケー キの様な展伸結晶粒の生成と深い関係にあると考えられ ていたが，1962 年 Burns ら (1)によって深絞り性を支配 するのは鋼板の集合組織である事が明らかにされた。そ して深絞り性に優れた $\mathrm{A} 1$ キルド鋼板はシャープな集合 組織を持つ事が見出され，集合組織形成に及ぼす製造条 件の影響や再結晶挙動と AlN の析出の関連などについ て膨大な研究が世界的に行われる様になり，この研究ブ 一ムは 1970 年位まで続いた。 その詳細はとてもここで 述べ切れないが, 微細な $\mathrm{A} 1 \mathrm{~N}$ の析出が再結晶の開始と 同期して生ずると深絞り性に好ましい\{111\}方位の優先 成長が促進されると考兄られ，そのための化学成分，熱 延条件，焼鈍加熱速度などの効果が検討された。例光ば 図 $1^{(2)}$ は焼鈍加熱速度と $\bar{r}$ 值の関係を示したものである が，一般に加熱速度が遅い程 $\vec{r}$ 值は高くなっており，ま

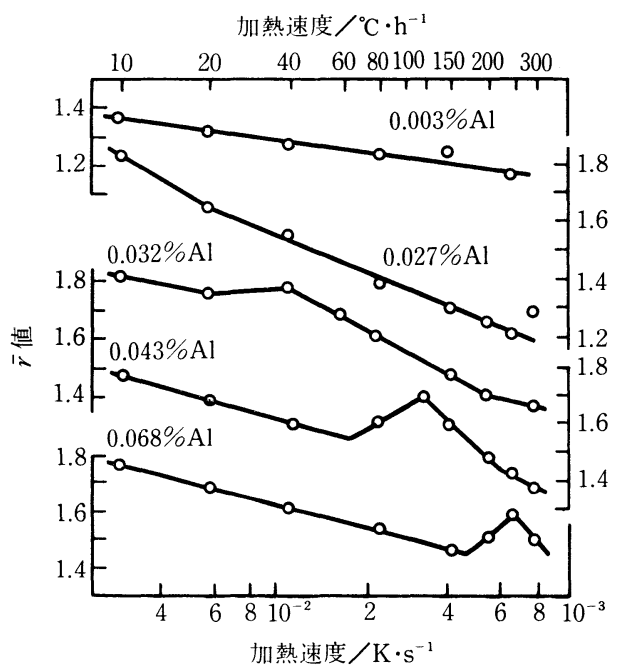

図 $1 \mathrm{~A} 1$ キルド鋼の $\vec{r}$ 值に及ぼす加熱速度と $\mathrm{A} 1$ 量 の効果 ${ }^{(2)}$.
た, $\mathrm{Al}$ 量と加熱速度に応じて $\vec{r}$ 值に極大值が観察され る。この極大值は $\mathrm{A} 1$ 量が高くなるほど急熱側に移動し て扣り, 再結晶時有効に働く $\mathrm{A} 1 \mathrm{~N}$ の析出条件に対応し ていると考兄られる。しかし A1N が集合組織を制御す る機構については他の析出物の場合も含めて十分解明さ れたとはいえない。

\section{（2） OCA 脱炭深絞り用鋼板}

1957～1958 年頃米国 Lee Wilson 社によって開発され たオープンコイル焼鈍炉は, 数年後に早くも我が国に尊 入され, 川鉄千葉, 富士鉄広畑, 八幡戸畑など各所で次 々に深絞り用鋼板製造の武器として使用される様になっ た。この方式ではワイヤースペーサーの巻込みによって 鋼板が雾囲気ガスと自由に接触出来るため, 雾囲気ガス を適当に選択する事によって脱炭脱窒が出来る外，焼付 きがないため焼鈍温度を高めて高品質を得る事が出来 る。またコイル全長を通して均一な機械的性質を得る 事が出来る利点もあった．脱炭には湿 HNX ガスが，ま た，脱窒にはアンモニア分解ガスが使用された．図 2 に キャップド OCA 脱炭鋼板 $(\mathrm{A})$ と $\mathrm{A} 1$ キルド OCA 脱炭鋼 板 (B) の強度一延性バランスを他鋼種と比較して示した. SPCC, SPCD，SPCEN はそれぞれ一般用，絞り用，非時 効保証深絞り用冷延鋼板である。A，B 鋼共伸びの大き い秀れた軟質鋼板である事が分かる．図３には同様に $n$ 值と $\bar{r}$ 值のバランスを示した．特に $\mathrm{A}$ 鋼はキャップド鋼 でありながら深絞り $\mathrm{Al}$ キルド鋼 (SPCEN) とほぼ同等の $\bar{r}$ 值と, 高 $n$ 值に代表される優れた張出し性を示してい る。焼鈍温度を高めると $\bar{r}$ 值は向上するが場合によって は異常粒成長を生じ製品の加工時に肌荒れを起す心配が あった。 それで $\bar{r}$ 值を高める他の方法としてリムド鋼母 材に $\mathrm{P}$ と $\mathrm{Sb}, \mathrm{Bi}, \mathrm{Nb}, \mathrm{Pb}$ の中の 1 種または 2 種以上を添 加した KTS 鋼板と呼ばれる鋼種が川崎製鉄によって開 発された ${ }^{(3)}$. この場合 $\mathrm{P}$ 含有量は $0.010 〜 0.040 \%, \mathrm{Sb}$ な ど併用元素の量は 0.003〜0.05\% 添加されている．表 2

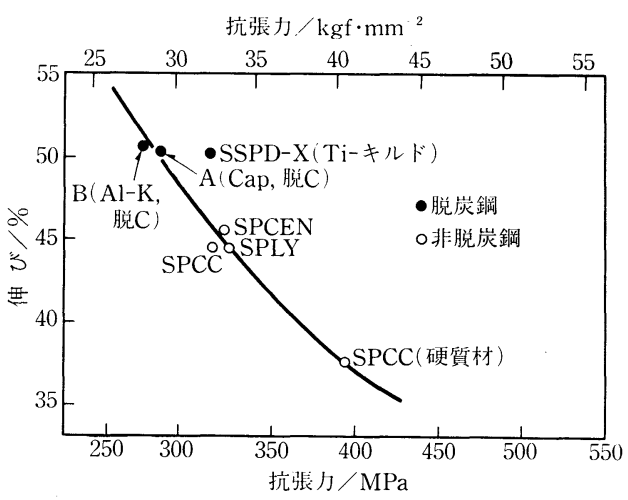

図 2 OCA 脱炭冷延鋼板の強度 - 延性バランス. 


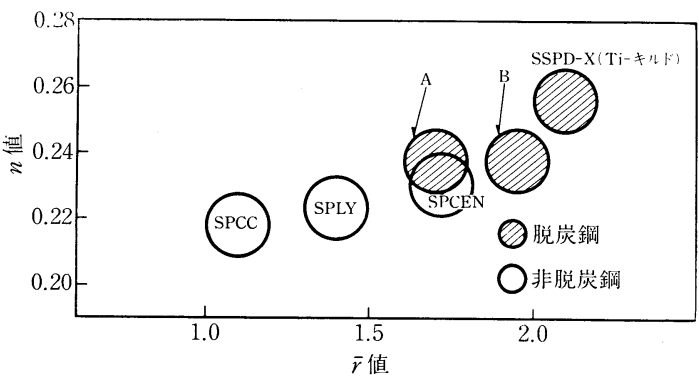

図 3 OCA 脱炭冷延鋼板の $n$ 值と $\bar{r}$ 值のバランス.
この結果, 従来鋼 (SPC) の降伏点が $215.6 \mathrm{MPa}(22$ $\mathrm{kgf} / \mathrm{mm}^{2}$ ) 程度であったのに対し, 本鋼板 (SPY)では $156.8 \mathrm{MPa}\left(16 \mathrm{kgf} / \mathrm{mm}^{2}\right)$ まで低下した。この低降伏点鋼 板では仕上温度が $\mathrm{Ar}_{3}$ 変態点を切っているため板面に 平行な $\{100\}$ 集合組織が形成され製品の $\vec{r}$ 值は劣化す る. 従って用途としてドアアゥターの様に比較的単純な 成形部品に適用された。また、リムド鋼では歪時効によ って調質圧延後の降伏点が再上昇するので $\mathrm{V}$ の様な窒化 物形成元素の添加が検討された ${ }^{(7)}$. V 添加鋼の表面品質

表 2 KTS 鋼板の化学成分と機械的性質 ${ }^{(3)}$.

\begin{tabular}{|c|c|c|c|c|c|c|c|c|c|c|c|c|c|c|}
\hline & \multicolumn{8}{|c|}{ 化 学 成 分 $(\%)$} & \multicolumn{5}{|c|}{ 機 械 的 性 質 } & \multirow{2}{*}{$\begin{array}{c}\text { ASTM } \\
\text { 粒 度 } \\
\text { No. }\end{array}$} \\
\hline & C & $\mathrm{P}$ & $\mathrm{A} 1$ & $\mathrm{Sb}$ & $\mathrm{Bi}$ & $\mathrm{Nb}$ & $\mathrm{Pb}$ & $\mathrm{N}$ & $\bar{r}$ & $\begin{array}{c}\mathrm{El} \\
(\%)\end{array}$ & $\left|\begin{array}{c}\mathrm{TS} \\
(\mathrm{MPa})\end{array}\right|$ & $\left|\begin{array}{c}\mathrm{YP} \\
(\mathrm{MPa})\end{array}\right|$ & $\begin{array}{l}\mathrm{YE}^{*} \\
(\%)\end{array}$ & \\
\hline 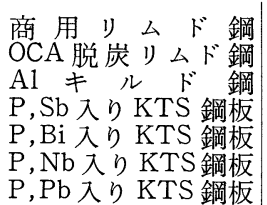 & $\begin{array}{l}0.055 \\
0.006 \\
0.043 \\
0.006 \\
0.008 \\
0.006 \\
0.006\end{array}$ & $\begin{array}{l}0.010 \\
0.010 \\
0.008 \\
0.032 \\
0.034 \\
0.035 \\
0.030\end{array}$ & $\begin{array}{c}\operatorname{tr} \\
\operatorname{tr} \\
0.043 \\
\operatorname{tr} \\
\operatorname{tr} \\
\operatorname{tr} \\
\text { tr. }\end{array}$ & $\begin{array}{c}\text { tr. } \\
\text { tr. } \\
\text { tr. } \\
0.018 \\
\text { tr. } \\
\text { tr. } \\
\text { tr. }\end{array}$ & $\begin{array}{c}\text { tr. } \\
\operatorname{tr} \\
\operatorname{tr} \\
\operatorname{tr} \\
0.010 \\
\text { tr. } \\
\text { tr. }\end{array}$ & $\begin{array}{c}\text { tr. } \\
\text { tr. } \\
\text { tr. } \\
\text { tr. } \\
\text { tr. } \\
0.009 \\
\text { tr. }\end{array}$ & $\begin{array}{c}\operatorname{tr} \\
\operatorname{tr} \\
\operatorname{tr} . \\
\operatorname{tr} \\
\operatorname{tr} \\
\operatorname{tr} \\
0.035\end{array}$ & \begin{tabular}{|l|l|l}
0.0025 & 1 \\
0.0008 & 1 \\
0.0058 & 1 \\
0.0010 & 1 \\
0.0006 & 1 \\
0.0008 & 1 \\
0.0006 & 1
\end{tabular} & $\begin{array}{l}1.07 \\
1.40 \\
1.55 \\
1.76 \\
1.70 \\
1.70 \\
1.71\end{array}$ & $\begin{array}{l}45 \\
51 \\
47 \\
47 \\
46 \\
47 \\
47\end{array}$ & \begin{tabular}{|l|}
321.7 \\
277.5 \\
299.1 \\
296.2 \\
324.6 \\
313.8 \\
305.9
\end{tabular} \mid & $\mid \begin{array}{c}259.9 \\
176.5 \\
- \\
- \\
- \\
-\end{array}$ & $\begin{array}{l}3.0 \\
1.0 \\
0.0 \\
0.2 \\
0.0 \\
0.0 \\
0.0\end{array}$ & $\begin{array}{l}9.6 \\
7.1 \\
8.2 \\
7.3 \\
7.5 \\
7.0 \\
7.4\end{array}$ \\
\hline
\end{tabular}

* $\mathrm{YE}$ 室温で $5.26 \mathrm{Ms}$ ( 6 ケ月) 時効後の降伏点伸び $\left(9.81 \mathrm{MPa}=1 \mathrm{kgf} / \mathrm{mm}^{2}\right)$

にKTS の特性值を示すが $\bar{r}$ 值は約 1.70 と SPCEN に 等しい值を示している.

OCA 炉は現在でもホーロー鋼板や一部の脱炭鋼板の 製造に使用されているが，大きなトンンドとして鋼塊 法 - OCA 脱炭といら製造方式は今や真空脱ガスー連続鋳 造 - 連続焼鈍といら新しいプロセスに転換されつつある といってよい.

\section{（3）リムド低降伏点鋼板}

吉田 ${ }^{(4)}$ によれば薄板のプレス性は，（1) 破壊なく成形 し得る変形能力 $=$ 成形性, (2) 変形中除荷後所定形状寸 法を得る能力二形状性, に大別出来る. 更に吉田 ${ }^{(5)}$ は形 状性が材料の降伏点によって支配される事を指摘し, こ の指摘に基づいて低降伏点鋼板が開発された。降伏点を 下げるにはPetch の式に従って結晶粒径を大きくすれば よいが，製造条件としては熱延仕上温度を $\mathrm{Ar}_{3}$ 点以下 とし巻取り温度を出来るだけ高くした熱延板を冷延後, 出来るだけ高温で長時間焼鈍する方法が八幡製鉄所にお いて検討された。 熱延の仕上温度と巻取り温度が熱延板 の結晶粒度に及ぼす影響を図 4 に示した。製品のグレー ドや製造箇所によって製造条件は異なるが，一例として 下記の製造条件が報告されている(6).

\section{鋼 種}

仕上温度

巻取り温度

焼鈍温度

調質压延

\section{リ ムド 鋼}

$$
1073 \mathrm{~K}\left(800^{\circ} \mathrm{C}\right) \pm 20 \mathrm{~K}
$$

最低 $913 \mathrm{~K}\left(640^{\circ} \mathrm{C}\right)$ $973 \mathrm{~K}\left(700^{\circ} \mathrm{C}\right)-7.2 \mathrm{ks}(2 \mathrm{~h})$ 保定 伸び率 $1 \%$
はリムド鋼並みに優れている事も有利であった。この鋼 板は SPY-2 と呼ばれたが製造例としては 0.03〜0.04\% のVを添加した低炭素鋼を熱延時 $1023 \mathrm{~K}\left(750^{\circ} \mathrm{C}\right)$ 程度で 巻取り冷延した後 $983 \mathrm{~K}\left(710^{\circ} \mathrm{C}\right)$ で焼鈍する. SPY-2 は ローラーレベリングを必要とせずフロントフェンダー， インナードアパネル等に適用され良好な成績を示したが $\mathrm{V}$ 価格の高騰もあって 1960 年代後半に誕生した $\mathrm{Al}$ コ アキルド鋼に置き換って行った。

\section{(4) Al コアキルド 鋼板}

$\mathrm{A} 1$ キルド鋼板は深絞り用鋼板として一般用のリムド 鋼板, キャップド鋼板と共に生産の主流を占めて来たが $\mathrm{Al}_{2} \mathrm{O}_{3}$ 系介在物のため表面性状が劣るという本質的な問 題があった．この対策として未脱酸鋼を取鍋から鋼塊の 押湯部まで注入した後, しばらく放置してリミングアク ションにより厚さ $5 \sim 35 \mathrm{~mm}$ 程度の健全リム層の凝固部 分を表面に形成せしめ, 次いで通常の半量 $1.0 \mathrm{~kg} /$ 溶鋼 トン程度の $\mathrm{A} 1$ を投入して脱酸する $\mathrm{A} 1$ コアキルド方式 と呼ばれる造塊法が開発された。

この鋼はリムド鋼相当の健全な表面と $\mathrm{A} 1$ キルド鋼に 匹敵する加工性を持つため, 1965 年頃から深絞り用鋼板 として本格的に採用され， $\mathrm{A} 1$ キルド鋼といえば $\mathrm{A} 1$ コア キルド鋼を指す様になった。取鍋 $\mathrm{A} 1$ 脱酸鋼ではスラブ 全面のスカーフィングを必要とし，そのスカーフロスは

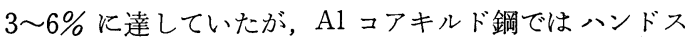




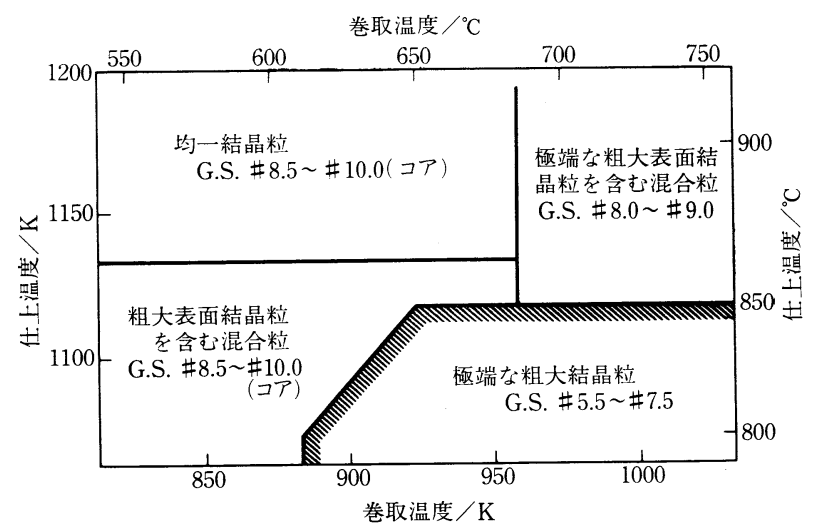

図 4 低炭素熱延鋼帯の結晶粒構造におよぼす仕上 温度と巻取温度の影響の模式図 ${ }^{(6)}$ 。

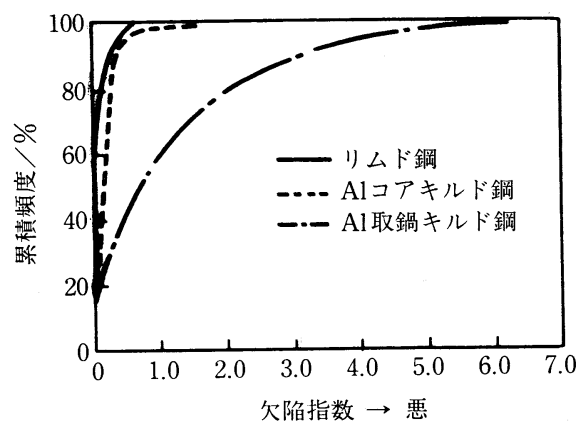

図 5 リムド鋼， $\mathrm{A} 1$ コアキルド鋼， $\mathrm{A} 1$ 取鍋キルド 鋼の表面欠陷発生率 ${ }^{(8)}$.

カーフでよくそのロスも $0.1 \%$ 程度であったからこの製 造法はたちまち普及する様になった。リムド鋼，コアキ ルド鋼, 取鍋キルド鋼の表面欠陷発生率の比較を図 $5^{(8)}$ に示したがコアキルド鋼はリムド鋼に近い優れた表面性 状を持っている事が分かる。一方，コアキルド鋼では A1 を鋼塊中に添加するため空気中の窒素と十分接触し て A1N を形成する機会に乏しく集合組織制御が十分に 行われない場合があった。すなわち鋼中の窒素量はリム ド鋼並みなのでむしろ窒化マンガン等で加窒して窒素量 を0.0020\% 以上に増加させればこの現象を回避する事 が出来た，そして十分な $\mathrm{AlN}$ を含有するコアキルド鋼 は C 量や $\mathrm{Si}$ 量が少ないため取鍋キルド鋼より良好な機 械的性質を有している。この様に鋼塊法の $\mathrm{Al}$ ユアキル ド鋼は深絞り用鋼板の主流となったが, 連続鋳造時代に 入ると時流に抗する事が出来ず消隇してしまった.

\section{(5) $\mathbf{T i}$ キルド深絞り用鋼板}

特願昭 41-9115 “プレス成形性の優れた冷 延 鋼 板”(清 水他 4 名) は当時の八幡製鉄から出願され，後に SSPD$\mathrm{X}$ といら商品名で世界的に広く知られる様になった深絞 り用鋼板の記念すべき特許である.

この鋼は Ti キルド鋼で降伏点が $137.2 \mathrm{MPa}$ (14 kgf/ $\left.\mathrm{mm}^{2}\right)$ 程度と低く,伸び $(\approx 50 \%), \bar{r}$ 值 $(\approx 2.0)$ 飞 優れた理想的な深絞り用鋼板であるが，開発の 端緒は厚板関係の研究者が「Ti を添加すると 降伏点が下り過ぎて厚板には使えない」といっ ているのを聞いてヒントにしたといわれる。こ こにもテクノロジー・トランスファーの大切さ を見る思いがする.

この鋼は侵入型固溶元素の $\mathrm{C}, \mathrm{N}$ や外に $\mathrm{S}$ を 固定するためその $\mathrm{Ti} / \mathrm{C}$ 比を約 10 倍程度に設 定されていた. 1964 年の試作当時から真空脱が スによって $\mathrm{C} \approx 0.01 \%$ 程度の極低炭素ベース で製造されていたが，その後の真空脱ガス設備 の進歩により $\mathrm{C}$ 量は半減し,それに応じて $\mathrm{Ti}$ 量 も削減され合金コストの低減が可能となった。

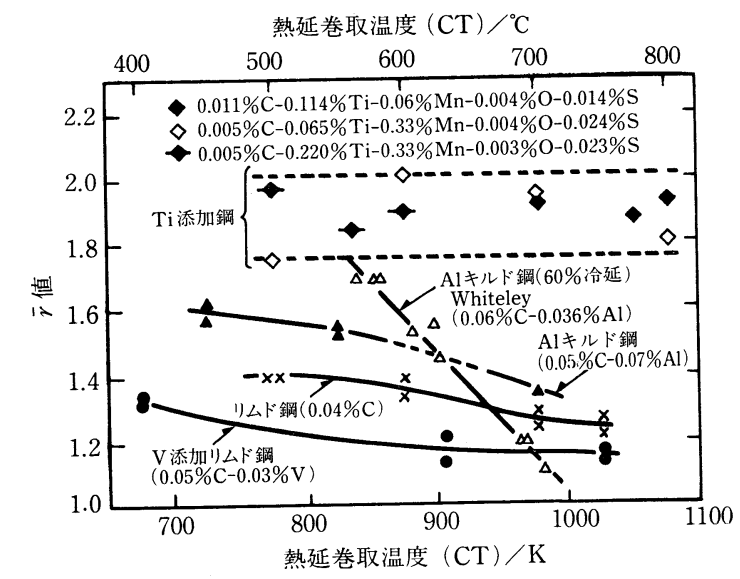

図 6 冷延低炭素鋼板 $\bar{r}$ 值に打よぼす巻取温度の影 響 (冷延率: 68７0\%，焼鈍： $973 \mathrm{~K}\left(700^{\circ} \mathrm{C}\right.$ ) $18 \mathrm{ks}(5 \mathrm{~h}){ }^{(9)}$.

烧鈍加熱速度 $(\mathrm{HR}) /{ }^{\circ} \mathrm{C} \cdot \mathrm{h}^{-1}$

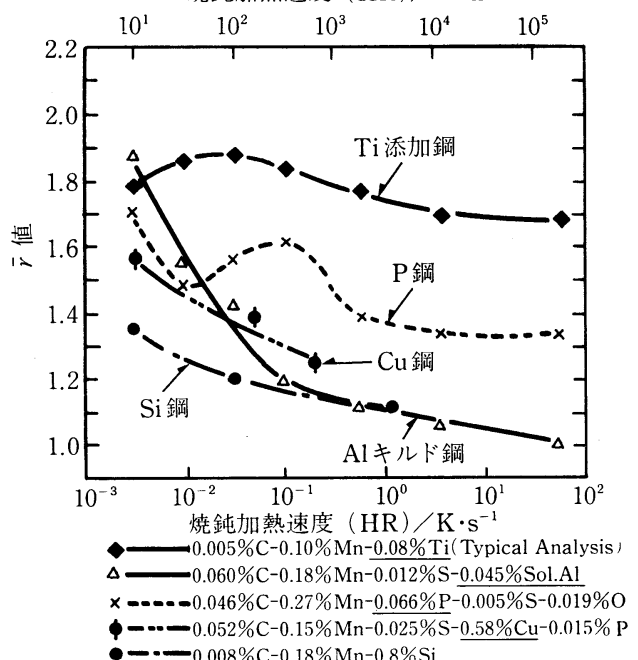

図 $7 \bar{r}$ 值に技よぼす焼鈍加熱速度の影響(冷延率 : $68 \sim 70 \%$, 焼鈍: $973 \mathrm{~K}\left(700^{\circ} \mathrm{C}\right)-18 \mathrm{ks}(5 \mathrm{~h})^{(9)}$. 
この鋼は C, $\mathrm{N}$ が Ti によって完全に固定されているた め $\mathrm{A} 1$ キルド鋼に見られる様な $\bar{r}$ 值に対する熱延巻取り 温度や焼鈍時の加熱速度依存性が全く存在しない.この 例が図 $6^{(9)}$ と図 $7^{(9)}$ に示されている。

$\mathrm{Ti}$ 添加が $\vec{r}$ 值を高める機構については $\mathrm{TiC}$ の微細析 出物説や, $\mathrm{Ti}$ が固溶している $\mathrm{C}, \mathrm{N}, \mathrm{S}$ 等を固定してマト リックスを浄化するといういわゆる純鉄説または Scavenging 説などの諸説が唱えられていたが，最近は東大 の阿部教授によって Mn-C ダイポールや Ti-C ダイポー ル説が提案され学会で今後論議を呼ぶものと期待され る。上に述べた様にこの鋼板は特性の加熱速度依存性を 持たないので連続焼鈍への適用性が大きく同種の鋼とし てTi の代りに Nbを添加したものも製造されている.

\section{（6）連続鋳造向リムド相当薄鋼板}

1973 年の第 1 次石油ショック以降製鉄会社にとって 省エネルギーが最大の命題となり, 分塊圧延を省略出来 る連続鋳造法は体質改善の中心技術となった。また，連 続鋳造法では鋼塊頭部の切捨てもなく高歩留りが得られ ると共に品質の均一性も高い。連続鋳造スラブは中心偏 析をある程度伴うが，薄板の場合は板厚方向の応力によ る剝離は殆ど問題にならないから連続鋳造メリットを享 受するのに最適の製品といえよう。連続鋳造には初め $\mathrm{A} 1$ キルド鋼やU.S. Steel 社で 1965 年頃開発された Riband 鋼と呼ばれる Si キルド鋼が用いられていた。乙 かし, 亜鉛めっきの密着性や冷延製品のテンパーカラー, あるいは合金コストの低減などの見地から Si を用いず 最少限の $\mathrm{Al}$ によって脱酸する連続鋳造用薄鋼板が各社 で競って開発された，成分系はどれも大体同じで何れも 低 $\mathrm{Al}$ ，低 $\mathrm{N}$ が骨子となって居り新日鉄材の一例 ${ }^{(10)}$ 表 3 に示す。製造上最大の問題はスラブ表面のピンホー ルの防止であるから安定した脱酸技術，すなわち $\mathrm{Al}$ 量 のコントロールが必要であり，このため真空脱ガスの軽 処理が前提となっている、日本鋼管の報告 ${ }^{(11)}$ にると この鋼種に护ける強度 - 伸びバランスはリムド鋼並みで $\mathrm{A} 1$ キルド鋼より良好である。 また， $\mathrm{A} 1 \mathrm{~N}$ の析出量が $\mathrm{A} 1$ キルド鋼より少ないため結晶粒形状はリムド鋼の様に等 軸細粒となって居り伸びや $\bar{r}$ 值の面内異方性は $\mathrm{A} 1$ キル ド鋼よりも小さい，深絞り性は $\mathrm{A} 1$ キルド鋼より劣るが 張出し性は良好であり, 図 $8^{(11)}$ に示す様にバルジ成形 においても細粒高延性のため $\mathrm{A} 1$ キルド鋼より優れた成 形限界を示す。これらの事から本鋼種はリムド代替鋼と して十分使用可能である。

表 3 連続鋳造向りムド相当薄鋼板化学成分例 ${ }^{(10)}$

(質量\%)

\begin{tabular}{c|c|c|c|c|c|c}
\hline \hline $\mathrm{C}$ & $\mathrm{Si}$ & $\mathrm{Mn}$ & $\mathrm{P}$ & $\mathrm{S}$ & $\mathrm{Al}$ & $\mathrm{N}$ \\
\hline 0.04 & 0.01 & 0.25 & 0.015 & 0.014 & 0.006 & 0.0022 \\
\hline
\end{tabular}

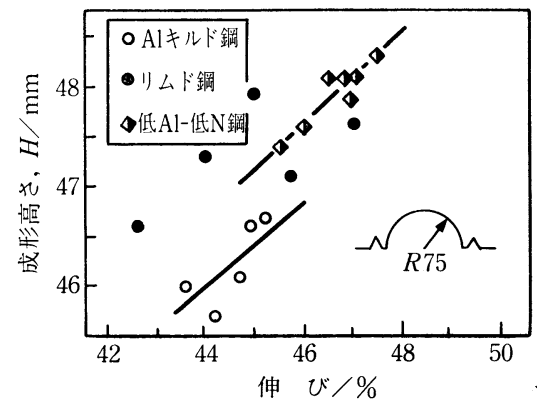

図 8 連続鋳造向低 $\mathrm{Al}$ - 低 $\mathrm{N}$ 鋼板の張出し特性 ${ }^{(11)}$

連続鋳造時代の波に乗って従来のリムド鋼，キャップ ド鋼は本鋼種に完全に置換され，本鋼種は今後も薄鋼板 の中心的品種となり続けよう。

\section{4. 自動車用高張力鋼板 (HSS) の開発}

1973 年の第 1 次石油ショックによってそれまで如何 に軟質の自動車用鋼板を作るかに腐心した鉄鋼業は, 一 転して高強度で加工性の良い鋼板の開発に直面する事と なった。幸い我が国には 1972 年から連続焼鈍技術が工 業化していた事, カー・メーカーとスチール・メーカー の共同研究組織があった事，などが HSS の実用化を推 進する上で大きな要因となった事は既に述べた通りであ る.

共同研究成果の例として外板パネル, 内板パネルの成 形に必要なHSSの機械的性質を図 9 と図 10 に示し た(12). 外板の成形には $\bar{r}$ 值と降伏比 $\mathrm{YR}$ が支配的であ り, 対象部品に応じて必要な $\bar{r}$ 值, YR は図 9 の 4 つの 領域に分類される事が分かった４つの領域を区分する $\bar{r}$ 值と YR の臨界值はそれぞれ 1.5 と0.6である。近年 開発された各種冷延 HSS の特性を 4 つの領域に記入し てある。同様に内板の成形には $\bar{r}$ 值と伸び $\mathrm{E} 1$ が支配的 である事が見出され，使用部品の成形度に応じて外板と 同じく 4 つの領域に区分される ${ }^{(12)}$. この状況が図 10 に

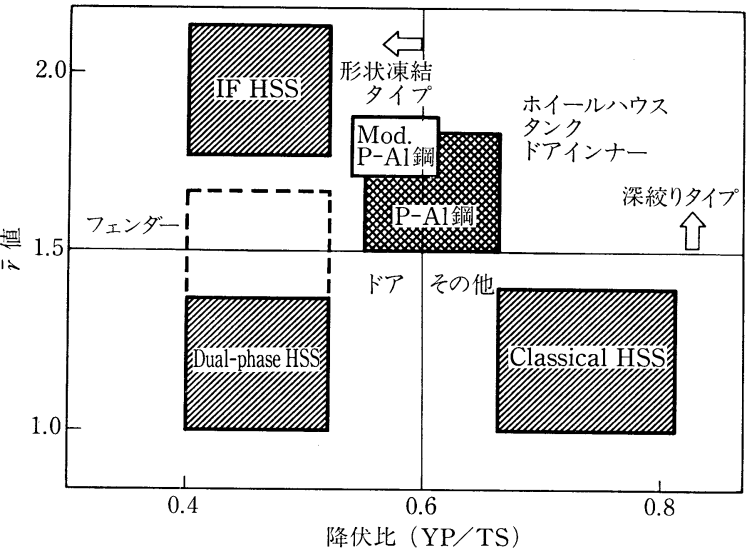

図 9 外板パネルの成形性支配因子と開発 HSS の 特性. 


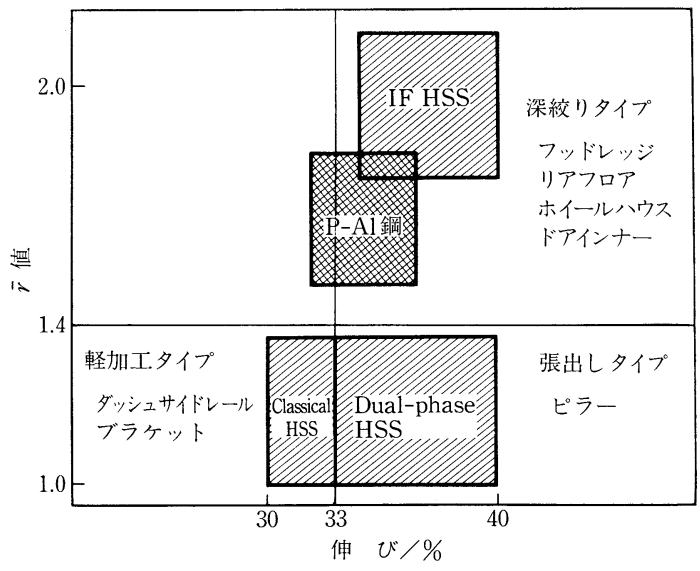

図 10 内板パネルの成形性支配因子と開発 HSS の 特性.

示され，最近開発された冷延 HSS の特性が合せて記入 してある４４つの領域を区分する $\bar{r}$ E 1 の臨界值はそ れぞれ 1.4 と $33 \%$ である.メンバー類については省略 する.

HSS の開発に当り，まず鋼の強化機構が製品の強度延性バランスに与える影響について検討された。 その結 果の一例を図 $11^{(12)}$ に示す。な扮，断らない限り強度は 抗張力で表示する. 加工硬化は強化機構として利用する には最も安価であるが，それによる強度 - 延性バランス は最も悪く少し成形する部品であれば殆ど使用に耐えな い. 析出強化では強度 $490 \mathrm{MPa}\left(50 \mathrm{kgf} / \mathrm{mm}^{2}\right)$ 以上の 鋼 板を比較的容易に作る事が出来るが強度 - 延性バランス は余り良くない，細粒強化鋼の延性は優れているが強化 能力としては約 $392 \mathrm{MPa}\left(40 \mathrm{kgf} / \mathrm{mm}^{2}\right)$ が上限である. $\mathrm{Si}, \mathrm{Mn}, \mathrm{P}$ 等による置換型固溶体強化に拉ける強度-延性 バランスは仲々良いがこの場合の強度上限も約 $490 \mathrm{MPa}$ である. Dual Phase 鋼は $490 \mathrm{MPa}$ 以上の強度と優れた 伸びを併せ持つ点優れているが

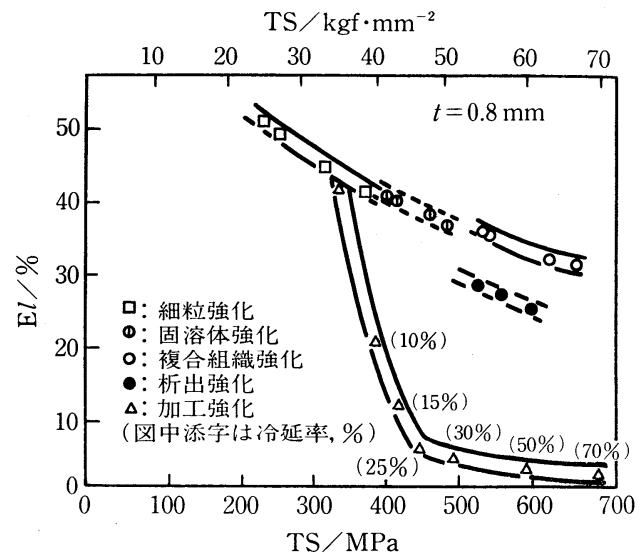

図 11 各種強化機構と強度 - 延性バランス (冷延鋼 板) ${ }^{(12)}$.
ある、ここではこれまでに開発されたHSS のらち，現 在中心的製品となっている $\mathrm{P}-\mathrm{A} 1$ 鋼と金属組織的に注目 された Dual Phase 鋼について開発の経緯等を以下簡単 に説明する。

\section{(1) P-Al 鋼板}

日本車はモノコック・ボデーであるから外板, 内板の 軽量化効果が大きいため，まずこれらの HSS 化が進行 した。アメリカの場合はこれと対照的にサスペンショ ソ, レインフォースメントなど, 構造部材, 補強部材の HSS 化から出発している. 図 12 に示す様に置换型固溶 元素の中で $\mathrm{P}$ は最も鉄に対する強化能力が高く(13)，ま た, 安価であり $\bar{r}$ 值も比較的損わないといらメリットが あるため外板, 内板用 HSS には現在 P 添加鋼が主流と なっている．Pは $\mathrm{Al}$ キルド鋼ベースに添加されるので $\mathrm{P}-\mathrm{A} 1$ 鋼と略記する.

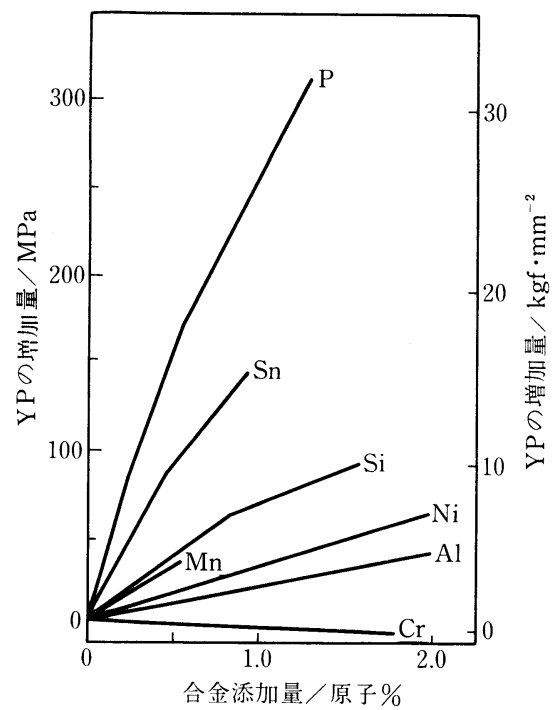

図 12 置換型固溶元素の鉄における強化能 ${ }^{(13)}$.

HSS といら材料が初めて国際的に討論されたのは 1973 年 10 月, Chicago の McHomick Place on the Lake で 開催された AIME の Materials Engineering Congress であったと思う。ここで筆者は $\mathrm{P}-\mathrm{A} 1$ 鋼や $\mathrm{Ti}$ 添加鋼な ど連続嗦鈍による各種 HSS に関する発表を初めて行っ $た^{(14)}$.

$\mathrm{P}-\mathrm{A} 1$ 鋼は深絞り用 $\mathrm{A} 1$ キルド鋼の製造法に準じて箱 焼鈍でも連続焼鈍でも製造出来るが，連続焼鈍の場合 C を $0.015 \%$ 程度に低減して焼鈍後の固溶 C 量をある程度 増加させ焼付硬化性 (BH 性)を大きくした Modified P$\mathrm{A} 1$ 鋼は優れた特性を有している ${ }^{(15)}$. 固溶 C 量が多いとい う事は歪時効の危険性もあるといら事になるが, $303 \mathrm{~K}-$ $2.63 \mathrm{Ms}\left(30^{\circ} \mathrm{C}-1\right.$ 力月) の常温時効では降伏点伸びの劣化 がなく $443 \mathrm{~K}-1.2 \mathrm{ks}\left(170^{\circ} \mathrm{C}-20 \mathrm{~min}\right)$ の塗料焼付処理で 
表 4 B 添加 Dual Phase 鋼の成分と機械的性質 ${ }^{(12)}$.

\begin{tabular}{c|c|c|c|c|c|c|c|c|c|c|c|c}
\hline \multicolumn{7}{c|}{ 化 } & 学 成 & \multicolumn{3}{|c|}{ 分 (質量\%) } \\
\hline $\mathrm{C}$ & $\mathrm{Si}$ & $\mathrm{Mn}$ & $\mathrm{P}$ & $\mathrm{S}$ & $\mathrm{Al}$ & $\mathrm{N}$ & $\mathrm{B}$ & $\begin{array}{c}\mathrm{YP} \\
(\mathrm{MPa})\end{array}$ & $\begin{array}{c}\mathrm{TS} \\
(\mathrm{MPa})\end{array}$ & $\begin{array}{c}\mathrm{E1} \\
(\%)\end{array}$ & $\mathrm{YR}$ & $\begin{array}{c}\mathrm{BH} \\
(\mathrm{MPa})\end{array}$ \\
\hline 0.055 & 0.06 & 1.47 & 0.017 & 0.004 & 0.023 & 0.0036 & 0.0040 & 234.4 & 466.8 & 38 & 0.50 & 124.5 \\
\hline
\end{tabular}

は析出硬化を示す C 量の領域が存在する事が指摘されて いる(16). 歪時効之焼付硬化性の関係は金属学的にも興 味ある問題であるう。

\section{(2) Dual Phase 鋼板}

Dual Phase 鋼板は一般にフェライトとマルテンサイ トの 2 相組織から構成されている。オーステナイトと フェライトの共存域に保定されている間に高純化された フェライトと, その後の急冷による硬いマルテンサイト の形成によって優机た強度 - 延性バランスと低降伏点化 が得られ，また BH 性も高い。こうして Dual Phase 鋼 は当初HSS の切札として世界的な注目を集めた。

Dual Phase 鋼といら認識が最初に学会で発表された のは 1975 年 Washington DC そ拈ける Micro Alloying 75 飞提出された速水，古川らの論文(17) ではないかと思 5. 同年飞住友金属の松岡ら ${ }^{(18)}$ が高 $\mathrm{Mn}$ 鋼の BAF 材に ついて降伏点が非常に下る事実を報告しているが，これ もDual Phase 鋼の特性を探知したものである。その翌 年 1976 年 2 月の SAE では GM の Rashid(19) が熱延板 VAN-80 を熱処理した結果を発表しているが未だ Dual Phase 鋼といら認識からの解析は行われていない。しか 乙翌 1977 年 10 月に Chicago で行われた AIME の Fall Meeting では Rashid ${ }^{(20)}$ が Dual Phase としての発表を 行い, Climax-Mo 社の Coldren $ら^{(21)}$ が 高合金鋼 $(0.05$ $\sim 0.07 \% \mathrm{C}-1.2 \sim 1.4 \% \mathrm{Mn}-0.9 \% \mathrm{Si}-0.4 \% \mathrm{Mo}-0.6 \% \mathrm{Cr}$ ) を通常条件で熱延し Dual Phase 組織といら認識を示し ている。事実この大会の Proceedings は “Formable HSLA and Dual Phase Steels” という標題で 1979 年に 刊行されている，従って Dual Phase 鋼といら認識が普 及したのは 1977 年位であったと思われるが，この間の 事情について間違っていればご叱正を頂きたい.

何れにしても Dual Phase 鋼は鋼板を $\mathrm{Ac}_{1}$ と $\mathrm{Ac}_{3}$ の 間の温度域に加熱保定した後 Ms 点以下まで泠却する訳 であるが，良好な Dual Phase 組織を得るためには化学 成分と適当な冷却速度の組合せが必要である ${ }^{(22)}$. 冷却 速度を速くすれば化学成分を低隇出来るがフェライト中 の固溶 $\mathrm{C}$ 量の増加汇よって延性が低下し，これを救済す るため過時効処理を行光ば降伏比が上昇する，逆に合金 成分を增加して比較的徐冷をすれば延性も降伏比も優れ たDual Phase 鋼板が得られるが合金コストが割高に なる．表 4 飞は B を添加して焼入性を高め合金量を低減
しながらガスジェット冷却により Dual Phase 鋼を製造 した例を示す。熱延 Dual Phase 鋼の製造は As Roll 型 と熱処理型があり，前者は更に高合金通常压延型と低合 金特殊圧延型に分かれるが詳細は別の解説 ${ }^{(12)}$ を参照さ れたい。

Dual Phase 鋼は当初オールマイティな材料であるか の様に期待されたけれどる現実には余り使用されていな い.この理由を一言でいえばュストと特性のバランスが 多量使用に踏又切らせるところまで未だ行っていないと いら事である。特性の中にはマルテンサイトの存在によ って $\bar{r}$ 值が低いという本質的な問題も含まれる。熱延 Dual Phase 鋼の場合，コイル内の特性変動が大きいと いら事が当初米国では重視されていたけれども，少なく とも日本の場合には新鋭ミルと製造技術の進歩によって それは無いといってよい。

\section{5. 結言}

自動車用鋼板の経過を簡単にまとめたが紙面の都合で かなり割愛した。しかしこの様な短文でもまとめてみて 社会環境とそれに対応する技術進歩のテンポの早さに改 めて驚かされた，そして今後も繰り返されるであろら種 々の変化に対応してゆくためには日頃から技術ポテンシ ヤルを貯えておく事が最も大切である，という最も平凡 な事を痛感した次第である。

\section{文献}

(1) R.S.Burns and R.H.Heyer : Blast Furn. Steel Plant, Sept. (1962), 861.

(2) S.Teshima and M.Shimizu : AIME Soc. Conf., 26(1965), 279. New York and London, Interscience.

（3）中里嘉夫, 伊藤庸, 佐々木 徹, 野原清彦: 川 崎製鉄技報, 1-2(1969)，169。

（4）吉田清太：塑性と加工，5(1964)，56.

（5）吉田清太, 津山義人, 昌谷陽二, 阿部邦夫 : 理化 学研究所報告, 41 (1965), 16.

（6）八幡製鉄株式会社：薄鋼板成形技術研究会資料, (昭 41-4)，80.

(7) N.Fukuda and M.Shimizu : Australian Inst. Met., 11[3] (1966), 198.

(8) K. F. Behrens and R. Hammer : J. Metals, Sept. (1967), 60.

（9）福田宣雄,清水峯男 : 塑性之加工, $13(1972), 841$.

（10）河野拓夫, 長沢元夫, 椿原 治, 細野和典, 江坂 一涁, 石飛精助：鉄と鋼，67 (1981)，1241. 
(11) 酒匂雅隆, 須田豊治, 荒木健治 : 鉄と鋼, 68 (1982), S 1425 .

(12) 武智 弘：鉄と鋼, 68(1982), 1244 .

(13) 武智 弘：塑性と加工, 21 (1980), 109.

(14) K.Toda, H.Gondoh, H.Takechi and H.Masui: Met.Trans., 7A (1976) , 1629.

(15) 武智 弘, 加藤 弘, 小山一夫, 川崎宏一, 豊田 洋民：鉄と鋼, $67(1981)$, S 461 .

(16) 岡本篤樹, 高橋政司, 日高貴夫 : 鉄々鋼, 66 (1980), A 209 .
(17) S. Hayami and T. Furukawa : Proceedings of Micro Alloying 75 2A, Washington DC, (1975), 78.

(18) T. Matsuoka and K. Yamamori : Met. Trans., 6A (1975) , 1613.

(19) M.S.Rashid : SAE Paper 760206, (1976) .

(20) M.S.Rashid : Conf.Proc.TMS-AIME (1977 Fall Meet.), 1.

(21) A.P. Coldren, G. Tither, A.Cornford and J. R.Hiam : Conf. Proc. TMS-AIME (1977 Fall Meet.), 205.

(22) 武智 弘：塑性と加工, $21(1980) ， 872$.

<新刊案内 >

\section{図解 ファインセラミックスの結晶化学 一無機固体化合物の構造之性質—}

F.S. ガラッソー 著 加藤誠軌, 植松敬三 訳

本書は，金属，金属間化合物および種々のセラミッ ク化合物などの無機質固体の結晶構造を系統的に記述 し, それらの結晶構造に由来する諸特性を解説したる のである．著者の意図するところは，すべての物質の 結晶構造を網羅することではない，むしろ現在とくに 関心を集めている化合物の結晶構造を特性と関係づけ て系統化することである，たとえば，強磁性をもつ $\mathrm{Cu}_{2} \mathrm{AlMn}$ 構造やスピネル，マグネトプランバイトお よびガーネット構造, レーザー用材料としての性質を もつホタル石構造とシーライト構造, 強誘電性をもつ ペロブスカイト構造, 超電導性をもつ $\beta$-タングステ ン構造, 半導性をもつセン亜鉛鉣構造などが, その特 性を生ずる結晶学的理由をあげて詳しく解説されてい る. 第 1 章では結晶学の基本㧊よび熱的, 電気的, 磁 気的, 誘電的, 光学的, 機械的などの種々の特性につ いての基本的事項が簡単にまとめられている。第 2 章 は周期律上の元素の結晶構造の要点が述べられてい る. 第 3 章から第 11 章では, 結晶構造をタイプごと に分けて解説している. $\mathrm{CsCl}$ 型, $\mathrm{NaCl}$ 型, $\mathrm{ZnS}$ 型,
NiAs 型, ペロブスカイト， スピネル，コランダム, 防タングステン型, グラファイトおよびそれらと関連 した結晶構造についてそれぞれ代表的化合物をあげ， その空間群, 対称, 原子座標, 格子定数データなどを 示し, いくつかの重要な性質については物性定数を表 示して詳しく解説している. 最終章では同種の化合物 毎に結晶構造のタイプを総括している。全体を通して 結晶模型の透視図を多数使用して複雑な結晶構造の原 子配列や充填の特徵および関連する結晶構造が良くわ かるように工夫されている，また，同じ結晶構造をも つ化合物がしばしば同じ性質を示すことが強調されて おり, 本書を通読すれば重要な性質をもつ化合物の結 晶構造のイメージを容易に思いらかべることができる ようになっている。な拉，原著ではとり上げられてい ない人工化合物の $\mathrm{Si}_{3} \mathrm{~N}_{4}$ については最後に 1 章が補わ れており，訳者みずから考案した結晶模型作製機(球 体穿孔機)を用いて作製した結晶模型による解説がな されている。

〔A5判 344頁 1984年 4,500円（株)アグネ技術センター】 